\title{
Pengajaran Musik Bambu (Angklung) untuk Meningkatkan Pembelajaran Seni Musik
}

\author{
Hikmawati Usman ${ }^{1}$, Nasaruddin ${ }^{2}$, Sayidiman ${ }^{3}$ \\ 1,2,3 Fakultas Ilmu Pendidikan,Universitas Negeri Makassar
}

\begin{abstract}
This study was conducted based on several factors such as the lack of students' knowledge in playing traditional music instruments and the lack of training to develop their talents. The result of this study showed that the main issue in training are 1) the students have not understand the importance of bamboo music instruments (angklung), 2) not many of the students play this bamboo instruments (angklung), 3) the students still lack of practicing play bamboo instruments (angklung).
\end{abstract}

Keywords: training, bamboo musical instruments (angklung), improving learning

\section{PENDAHULUAN}

Proses pembelajaran yang menyenangkan dan mengembangkan kreativitas mahasiswa adalah situasi yang saat ini dituntut untuk dikembangkan. Dalam hal ini, pengajar adalah salah satu pihak yang sangat bertanggung jawab. Karena pengajar memiliki peran dalam merencanakan dan melaksanakan proses pembelajaran di kelas.

Salah satu aspek yang dapat membangkitkan semangat membuat mahasiswa merasa senang mengikuti proses pembelajaran adalah penggunaan media pembelajaran yang tepat dan menarik. Dengan demikian, dalam membuat rencana pembelajaran, pengajar juga harus merencanakan media apa saja yang harus digunakan untuk mencapai kompetensi yang diharapkan.mahasiswa diharapkan mampu untuk mengidentifikasi sumber belajar yang ada, khususnya yang berada di sekitar lingkungan sekolah atau yang dibuat dengan menggunakan bahan-bahan yang sederhana.

Mahasiswa sebaiknya mengetahui bagaimana menggunakan media dan sumber belajar, termasuk bagaimana menggunakan alat bantu belajar secara benar dalam memberikan pembelajaran kepada siswanya. Alat peraga di SD merupakan suatu perangkat yang cukup penting untuk mencapai hasil belajar. Dewasa ini sebagai alat peraga, khususnya alat peraga telah dikembangkan untuk membantu proses belajar-mengajar dengan tujuan anak didik dapat lebih mudah memahami konsep.
Alat peraga yang akan dipergunakan dalam pembelajaran di SD, tidak semuanya harus diperoleh dari alat-alat buatan pabrik. Dalam beberapa hal guru dan siswa dapat merancang sendiri bekas atau benda-benda yang terdapat di sekitar sekolah yang murah dan mudah didapat. Dalam hal ini guru tentunya harus memiliki kreativitas yang tinggi untuk membuat dan merancang media pembelajaran yang sesuai dengan materi yang akan diajarkan di samping itu guru juga harus mampu menerapkan dalam kelas ketika materinya akan dipraktekkan.

Salah satu kreasi musik yang saat ini lagi trend adalah Bambu. Bambu adalah semacam alat musik yang sangat mudah ditemukan dan banyak alat musik yang dapat dibuat dari bahan dasar bambu. Seperti yang biasa kita lihat sekarang begitu banyak alat-alat musik yang terbuat dari bambu misalnya: Katto-katto, angklung, kolintang, gendong-gendong atau addarek (sejenis kolintang sederhana), sound of water, dan masih banyak lagi alat musik lainnya yang terbuat dari bahan dasar bambu.

Salah satu bahan pembuatan alat peraga terutama untuk alat musik yang lebih mudah ditemukan adalah bambu. Selain mudah di buat bambu juga sangat mudah didapatkan di lokasi mitra. Pengolahan bahan dasar bambu sangat mudah untuk dibuat menjadi alat musik ritmis maupun ritmis melodis seperti kannong-kannnong, 
gendong-gendong sejenis alat musik kolintang bambu.

Dengan melihat kenyataan di atas, perlu kiranya diadakan suatu pelatihan dan pengajaran musik bambu khususnya musik angklung dapat diterapkan di kelas, karena tingkat kemampuan keterampilan mahasiswa di PGSD masih di bawah rata-rata, sehingga target yang diharapkan bisa tercapai dan disiplin ilmu bisa merata pada mahasiswa khususnya mahasiswa angkatan 2016 nantinya dapat mengajar pendidikan keterampilan atau SBK (Seni budaya dan keterampilan) di sekolah dasar.

Identifikasi kebutuhan pelatihan adalah meneliti adanya kekurangan pengetahuan, keterampilan dan sikap pada seseorang dikaitkan dengan tuntutan pekerjan. Kebutuhan training atau pelatihan bahkan penyuluhan dimaksudkan untuk memenuhi tuntutan jabatn saat ini yang akan datang atau jabatan lainnya. Tidak semua kekurangan dan kelemahan suatu instansi dapat diselenggarakan dengan training atau pelatihan. Kreativitas dalam merancang media yang tepat untuk setiap materi yang akan diajarkan adalah tuntutan yang tidak dapat dipungkiri oleh setiap pengajar. Permasalahannya adalah mahasiswa masih kesulitan membaca notasi musik.Hal ini disebabkan oleh beberapa faktor, salah satunya salah karena mahsiswa PGSD tidak pernah mendapatkan pembelajaran musik bambu (angklung) sebelumnya.

Berdasarkan faktor ini, maka dapat dirumuskan bahwa pengetahuan dan keterampilan mahasiswa tentang pelatihan dan pengajaran masik bambu (angklung) khususnya mahasiswa PGSD UPP Makassar Angkatan 2016 FIP UNM ini masih dianggap masih kurang, di samping itu juga belum pernah mendapat pelatihan tentang pengajaran musik bambu (angklung) untuk melakukan kegiatan yang dapat memberi peluang kepada mereka untuk mengembangkan pengetahuan keterampilan yang dimiliki.

Berdasarkan fakta inilah, kegiatan pelatihan tentang pelatihan dan pengajaran musik bambu (angklung) ini perlu diterapkan pada mahasiswa UPP Makassar khiususnya angkatan 2016 untuk dijadikan sebagai salah satu media pembelajaran.
Adapun rumusan masalahnya adalah sebagai berikut:

a. Bagaimana mahasiswa dapat memahami konsep dasar seni dalam mata kuliah seni musik di SD?

b. Bagaimana mahasiswa dapat memahami teknik permainan musik bambu (angklung)?

c. Bagaimana mahasiswa dapat mempraktekkan alat musik bambu (angklung) dalam kelas?

\section{METODE PELAKSANAAN}

Metode yang dilaksanakan pada kegiatan pengabdian pada masyarakat ini adalah metode ceramah dan metode demonstrasi. Metode ceramah, dilakukan untuk memperkenalkan materi tetang alat dan bahan dari alat musik bambu (angklung). Sedangkan metode demonstrasi yakni memberikan praktek serta teknik memainkan alat musik bambu (angklung) langsung pada peserta

Selama pelatihan ini metode observasi, ceramah, dan demonstrasi langsung dan dilengkapi dengan beberapa metode antara lain: tanya jawab, diskusi, praktek dan evaluasi hasil pekerjaan. Kegiatan dalam pelatihan ini yaitu:

a. Observasi, yaitu mengadakan orientasi terhadap permasalahan yang dihadapi oleh mahasiswa PGSD angkatan 2016 yang menjadi sasaran pelaksanaan kegiatan ini.

b. Ceramah, dilakukan untuk memperkenalkan beberapa materi tentang cara memainkan, dan teknik bermain alat musik bambu (angklung).

c. Demonstrasi, memberikan praktek langsung pada peserta khususnya cara atau teknik bermain musik bambu (angklung).

\section{HASIL DAN PEMBAHASAN}

\section{A. Hasil yang Dicapai}

Kegiatan pengabdian yang dilaksanakan pada tanggal 4 Mei- 4 November 2018. menunjukkan hasil sesuai dengan apa yang diharapkan sebelumnya. Pelatihan ini dapat memberikan pengetahuan keterampilan baru bagi mahasiswa PGSD UPP Makassar angkatan 2016 tentang permainan alat musik bambu (angklung).

Selama kegiatan berlangsung, semua mahasiswa memperlihatkan antusias dan partisipasi yang 
tinggi karena materi pelatihan yang diberikan adalah sesuatu yang sifatnya masih baru buat mereka. Partisipasi tersebut ditunjukkan mulai kegiatan ceramah, kegiatan demonstrasi dan kegiatan penutup. Partisipasi aktif sangat terlihat ketika peserta mulai memainkan alat musik bambu (angklung) dengan memainkan solmisasi.

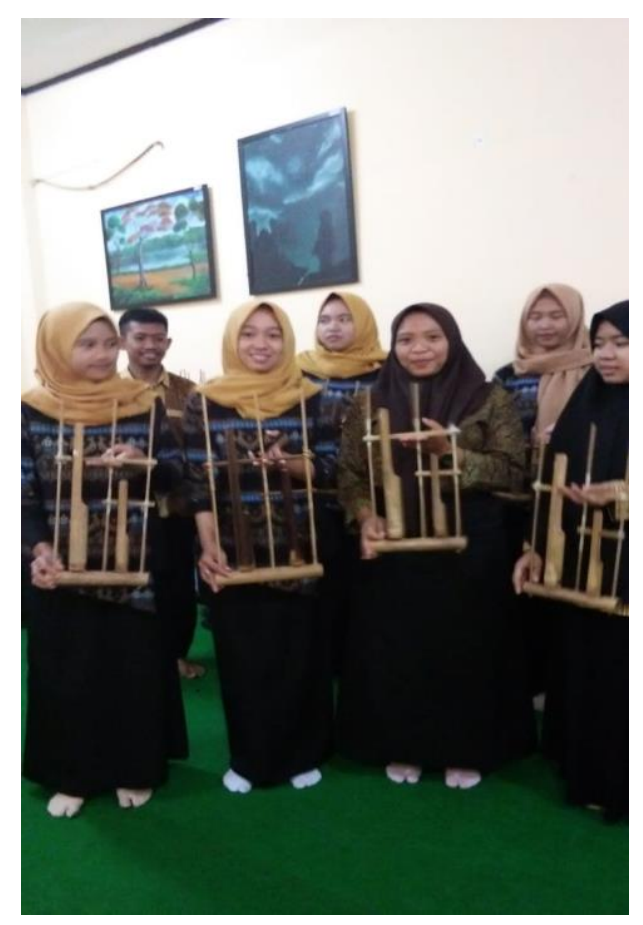

Gambar 1. Latihan solmisasi

Berdasarkan hasil pengamatan selama berlangsungnya pelatihan nampak bahwa $90 \%$ mahasiswa telah mampu memperlihatkan peningkatan yang signifikan, sedangkan sisanya masih perlu mendapatkan latihan tambahan agar mahasiswa bisa memainkan alat musik bambu(angklung) dan memperagakan di depan kelas. Berdasarkan pengamatan selama pelatihan, bahwa pengetahuan dan keterampilan mahasiswa tentang cara dan teknik bermain musik bambu (angklung) terlihat sangat baik. Hal ini ditunjukkan oleh partisipasi aktif mahasiswa selama pelatihan mulai dari belajar bermain alat sampai pada praktek memainkan alat musik bambu ini.

Hasil pengamatan tersebut didukung dengan hasil wawancara lepas dengan peserta, sebagian besar mengatakan bahwa kegiatan pengabdian ini sangat bermanfaat buat mereka. Pengetahuan dan keterampilan yang didapatkan dalam pelatihan tersebut akan mereka aplikasikan di sekolah nantinya.

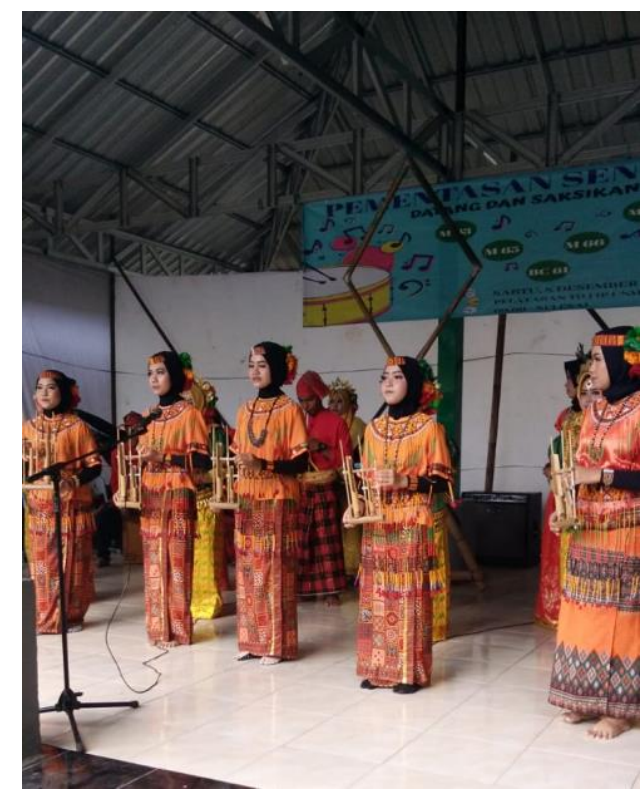

Gambar 2. Pementasan musik angklung

\section{B. Pembahasan (Materi Kegiatan)}

1. Mengenal musik bambu angklung

Angklung merupakan alat musik asli Indonesia yang terbuat dari bambu. Kata angklung konom berasal dari bahasa sunda (angkleung-angkleungan) yang menggambarkan gerak tubuh para pemain angklung yang berayun-ayun seiring irama yang dibunyikan. Alat musik ini dibunyikan dengan caradigoyangkan (bunyi yang disebabkan oleh benturan badan pipa bambu) sehingga menghasilkan bunyi yang bergetar. Angklung tumbuh dan berkembang pada masyarakat suku sunda (Jawa Barat) dan digunakan untuk upacara yang berkaitan dengan tanam padi. Sistem nada angklung pada awalnyaberlaraskan pelog, selendro, madenda angklung jenis ini disebut angklung buhun kemudian pak daeng soetigna membuat angklung berlaraskan diatonic.

Nada-nada angklung buhun dideskripsikan menjadi dogdog lonjor memiliki 3 nada, badud dan badeng memiliki 4 nada, dan angklung buncis memiliki 5 nada. Jenis-jenis angklung tersebut adalah sebagai berikut: 
a. Angklung Kenekes

Angklung ini sering dikenal sebagai angklung badui, digunakan untuk upacara menanam padi.

b. Angklung Gubrak

Angklung ini berasal dari Kampung Cipining

Kecamatan Cigudeg, juga digunakan untuk menghormati dewi padi.

c. Angklung Dogdog Lonjor

Angklung ini berasal dari masyarakat Banten selatan di daerah gunung halimun. Digunakan pada upacara seren taun menghormati dewi padi karena panen berlimpah.

d. Angklung Badeng

Angklung badeng berfungsi sebagai hiburan dan media dakwah penyebaran Islam, namun sebelumnya di Garut tepatnya di Kecamatan Malambong juga dipakai berhubungan dengan ritual padi.

e. Angklung Buncis

Angklung buncis dipakai sebagai media hiburan namun awalnya juga dipakai pada acara ritual pertanian yang juga berhubungan dengan tanaman padi.

\section{Teknik permainan angklung}

Memainkan sebuah angklung sangat mudah seseorang tinggal memegang rangkanya pada salah satu tangan (biasanya tangan kiri) sehingga angklung tergantung bebas, sementara tangan lainnya (biasanya tangan kanan) menggoyangnya hingga berbunyi. Dalam hal ini, ada 3 teknik dasar menggoyang angklung

a. Pertama, yang harus dilakukan adalah memposisikan angklung dengan lurus dan jangan sampai miring. Dan pastikan posisinya tabung yang tinggi berada disebelah kanan pemain sedangkan yang kecil berada disebelah kiri pemain. Kurulung (getar) merupakan teknik paling umum dipakai, dimana tangan kanan memegang tabung dasar dan menggetarkan ke kiri kanan berkali-kali selama nada ingin di mainkan.

b. Kedua, masih dalam keadaan posisi angklung yang lurus dimana tangan kiri memegang bagian atas simpul angklung sedangkan tangan kiri memegang bagian bawah. Cara meng- getarkannya adalah dengan menggunakan tangan kanan yang berada di bawah angklung sedangkan untuk tangan kiri jangan ikut menggoyangkan, tangan kiri difungsikan hanya untuk memegang bagian atas agar tidak jatuh. Goyangkanlah angklumg ke kiri dan ke kanan dengan cepat dengan begitu suara yang dihasilkan akan maksimal. Centok (sentak) adalah teknik dimana tabung dasar ditarik dengan cepat oleh jari ke telapak tangan kanan, sehingga angklung akan berbunyi sekali saja (stacato).

c. Tiga, apabila anda menggunakan angklung yang cukup besar ada baiknya bila angklung didekatkan dengan tubuh agar memudahkan kita dalam memainkannya apabila angklung yang dimainkan masih berukuran kecil cukup dipegang saja tetapi harus diberi jarak antara angklung tersebut dengan yang lain tidak saling bersenggolan dan mengganggu permainan anda. Tangkep mirip seperti kerulung namun salah satu tabung ditahan tidak ikut bergetar. Pada angklung melodi teknik ini menyebabkan angklung mengeluarkan nada murni (satu nada melodi saja, tidak dua seperti biasanya). Sementara itu pada angklung akompanimen mayor, teknik ini digunakan untuk dimainkan akord mayor (3 nada), sebab bila tidak ditangkep yang termainkan adalah akord dominan septim (4 nada).

\section{Berlatih angklung}

Angklung akan terdengar merdu dan megah jika di mainkan beramai ramai dengan kompak untuk itu diperlukan persiapan dan latihan yang cukup panjang, dipimpin pelatih yang cukup punya pemahamam musik umum maupun angklung.

Tahap-tahap persiapannya adalah:

a. Pilih lagu dengan aransemennya lagu yang cocok dimainkan dengan angklung, umumnya yang berirama riang dan jika bias ada bagian yang rancak sehingga bisa diimprovisasi dengan teknik centok. Lagu ini kemudian perlu di aransemen khusus untuk angklung dengan memiliki beberapa suara. 
b. Siapkan unit angklung sesuai aransemen dari aransemen angklung bisa diketahui berapa angklung yang diperlukan berdasar rentang nada lagu dan keseimbangan intonasinya.

c. Kumpulkan pemain dan distribusikan angklung kepada mereka jika ada pemain yang memegang banyak angklung harus diperhatikan agar si pemain tersebut tidak akan pernah memainkan 2 angklung saat bersamaan.

d. Pemanasan sebelum berlatih, sebaiknya melemaskan kaki dan tangan lalu lakukan gerakan-gerakan dasar untuk kerulung maupun centok bersama-sama.

e. Mempelajari lagu. Bersama-sama pelajari dan telusuri alur lagu mana bait-bait dan chorus yang harus di ulang. Perlahan-lahan lagu ini dibawah pimpinan kondaktor. Disarankan agar selama latihan awal semua nada dicentok saja jangan di kerulung dulu.

f. Menghapal not. Perlahan-lahan pemain diminta menghapal not-not lagu dan bagian permainannya.

g. Meningkatkan teknik. Ini tahap polesan akhir, dimana kondaktor bisa mulai memimpin dengan menekankan keserempakan permainan dinamika maupun penjiwaan.

h. Koreografi. Jika akan tampil di pentas bisa mulai dipikirkan impropisasi agar para pemain melakukan gerakan yang menarik tidak berdiri kaku terus menerus.

\section{Faktor pendukung}

Faktor pendukung yang paling dominan dalam pelatihan ini adalah minat mahasiswa yang sangat tinggi untuk mengikuti pelatihan alat-alat musik bambu (angklung). Hal ini disebabkan oleh pembelajaran semakin kedepan terlihat kualitas mahasiswa yang berprestasi baik. Di samping itu pembelajaran seni unutuk kurikulum 2013 tidak lagi termasuk muatan lokal tetapi sudah berdiri sendiri.

\section{Faktor penghambat}

Faktor penghambat dalam pelatihan yang paling dominan adalah durasi pelatihan yang cukup singkat sehingga, banyak mahasiswa khususnya mahasiswa PGSD angkatan 2016 ini yang meminta untuk diadakannya kembali pelatihan yang lebih intesif supaya bisa menghasilkan karya yang lebih baik.

6. Realisasi pemecahan masalah

Upaya mengatasi permasalahan yang dikemukakan di atas, maka alternatif pemecahan yang akan ditempuh sebagai berikut:

a. Mengadakan observasi awal atau orientasi lapangan mengenai masalah yang dihadapi mahasiswa yang menjadi sasaran pelaksanaan kegiatan ini.

b. Mengadakan bimbingan dan latihan tentang permainan alat musik bambu (angklung)

c. Memberikan petunjuk dan bimbingan tentang keterampilan memainkan alat musik bambu (angklung).

d. Memberikan kesempatan para peserta untuk membuat aransemen sendiri dengan menggabungkan lagu-lagu yang sudah dipelajari sebelumnya.

e. Mengadakan evaluasi, guna mengetahui tingkat pemahaman atau penguasaan keterampilan yang telah diberikan dalam bentuk memberikan kesempatan kepada mahasiswa untuk menanyakan beberapa hal yang belum dipahami atau dimengerti, yang dilakukan setelah materi pelatihan.

\section{KESIMPULAN}

Berdasarkan uraian sebelumnya maka, dapat disimpulkan bahwa program ini terlaksana dengan baik, lancar dan sesuai rencana, mahasiswa atau peserta memperlihatkan minat dan perhatian yang serius terhadap materi pelatihan, pengajaran alat musik bambu (angklung) dapat berjalan lancar. Dan berdasarkan hasil pengamatan menunjukkan bahwa sekitar 90\% mahasiswa PGSD angkatan 2016 mengalami peningkatan, sedangkan sisanya masih perlu banyak latihan tambahan. 